brain infarcts and white matter lesions increase stroke risk in the general population: the Rotterdam Scan Study. Stroke 2003;34:1126-1129.

3. Cupini LM, Diomedi M, Placidi F, Silvestrini M, Giacomini P. Cerebrovascular reactivity and Subcortical infarctions. Arch Neurol 2001;58:577-581.

4. Silvestrini M, Viticchi G, Falsetti L, et al. The role of carotid atherosclerosis in Alzheimer's disease progression. J Alzheimers Dis 2011;25:719-726.

5. Wahlund LO, Barkhof F, Fazekas F, et al. A new rating scale for age -related white matter changes applicable to MRI and CT. Stroke 2001;3:1318-1322.

\section{A COMPARISON OF TAU AND 14-3-3 PROTEIN IN THE DIAGNOSIS OF CREUTZFELDT-JAKOB DISEASE}

Andre Karch, Inga Zerr, Göttingen, Germany: Hamlin et al. ${ }^{1}$ compared validities of 2 commonly used CSF tests for sporadic Creutzfeldt-Jakob disease (sCJD) - 14-3-3 and total tau-and presented results contrary to previous studies. ${ }^{1-4}$ The present study is restricted to autopsy-confirmed cases, which seems reasonable, since neuropathology is the diagnostic gold standard in sCJD. However, using only autopsy-confirmed cases can also cause severe selection bias in a prospective setting, given that these tests are frequently requested in potentially treatable conditions. ${ }^{2,3}$ In the present study, clinicians were given results of 14-3-3 but not tau tests during the patient's lifetime. Autopsies were obtained in fewer than $10 \%$ of all initially referred patients. Thereby, decision about initiation of postmortem autopsy was directly dependent on 14-3-3 but not tau results. It seems a fair assumption that patients with CJD and negative 14-3-3 as well as patients without CJD and positive 14-3-3 were more likely to be autopsied than patients with consistent clinical history and 14-3-3 test results. Thereby, specificity and sensitivity of 14-3-3 are underestimated in this study design, which could explain differences in 14-3-3 validity when compared to previous studies. A final decision on test accuracy of 14-3-3 and total tau needs careful assessment in a prospective, multicenter study using standardized protocols for laboratory, clinical, and pathologic data. ${ }^{5}$

(C) 2013 American Academy of Neurology

1. Hamlin C, Puoti G, Berri S, et al. A comparison of tau and 14-3-3 protein in the diagnosis of Creutzfeldt-Jakob disease. Neurology 2012;79:547-552.

2. Chitravas N, Jung R, et al. Treatable neurological disorders misdiagnosed as Creutzfeldt-Jakob disease. Ann Neurol 2011;70:437-444.

3. Stoeck K, Sanchez-Juan P, Gawinecka J, et al. CSF biomarker supported diagnosis of CJD and rapid dementias: a longitudinal multicenter study over 10 years. Brain 2012; 135:3051-3061.

4. Sanchez-Juan P, Green A, Ladogana A, et al. CSF tests in the differential diagnosis of Creutzfeldt-Jakob disease. Neurology 2006;67:637-643.

5. DEMTEST (biomarker-based diagnosis of rapid progressive dementias: optimisation of diagnostic protocols). Available at: http://www.neurodegenerationresearch.eu/initiatives/ biomarker-transnational-call/results-of-funding-call/demtest/. Accessed April 9, 2013.

\title{
CORRECTIONS
}

Teaching NeuroImages: Basal ganglia involvement in facio-brachial dystonic seizures associated with LGI1 antibodies

In the article "Teaching NeuroImages: Basal ganglia involvement in facio-brachial dystonic seizures associated with LGI1 antibodies" by D. Plantone et al. (Neurology ${ }^{\circledR}$ 2013;80:e183-e184), figures 1 and 2 were transposed and should be reversed. The publisher regrets the error.

\section{Severe congenital $R Y R 1$-associated myopathy: The expanding clinicopathologic and genetic spectrum}

In the article "Severe congenital RYR1-associated myopathy: The expanding clinicopathologic and genetic spectrum" by D. Bharucha-Goebel et al. (Neurology ${ }^{\circledR} 2013 ; 80: 1584-1589$ ), there is an error in the author list. The fourth author should have read Kristen Zukosky. The editorial staff regrets the error. 


\section{Neurology}

\section{Teaching NeuroImages: Basal ganglia involvement in facio-brachial dystonic seizures associated with LGI1 antibodies \\ Neurology 2013;80;2081 \\ DOI 10.1212/WNL.0b013e31829926a2}

\section{This information is current as of May 27, 2013}

$\begin{array}{ll}\begin{array}{l}\text { Updated Information \& } \\ \text { Services }\end{array} & \begin{array}{l}\text { including high resolution figures, can be found at: } \\ \text { http://n.neurology.org/content/80/22/2081.2.full }\end{array} \\ \text { Permissions \& Licensing } & \begin{array}{l}\text { Information about reproducing this article in parts (figures,tables) or in } \\ \text { its entirety can be found online at: } \\ \text { http://www.neurology.org/about/about_the_journal\#permissions }\end{array} \\ \text { Reprints } & \begin{array}{l}\text { Information about ordering reprints can be found online: } \\ \text { http://n.neurology.org/subscribers/advertise }\end{array}\end{array}$

Neurology ${ }^{\circledR}$ is the official journal of the American Academy of Neurology. Published continuously since 1951, it is now a weekly with 48 issues per year. Copyright (C 2013 American Academy of Neurology. All rights reserved. Print ISSN: 0028-3878. Online ISSN: 1526-632X.

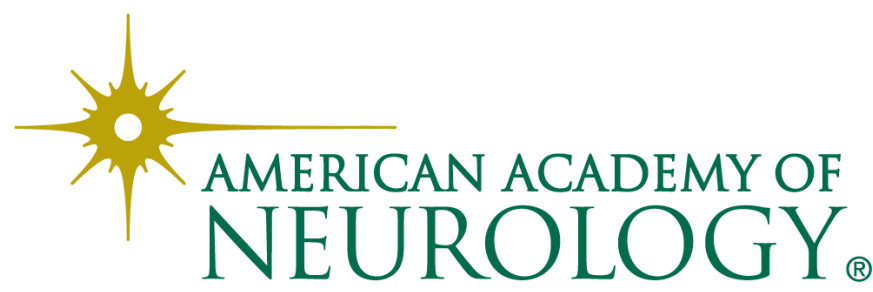

